\title{
Conference Report, “Approaching Shi'i Islam in the Academy", Leiden University Centre for Islam and Society (LUCIS), Wednesday 14 November 2018-Thursday 15 November 2018
}

\author{
Edmund Hayes \\ Leiden University, Leiden, The Netherlands \\ e.p.hayes@hum.leidenuniv.nl
}

The 2018 annual conference of the Leiden University Centre for Islam and Society (LUCIS) was held under the theme "Approaching Shici Islam in the Academy". This was perhaps the first conference of its kind in the Netherlands, whose universities, though possessing a strong tradition in Islamic studies and Persian studies, have not hitherto provided strong institutional support for Shii studies.

The conference was well attended and well received. While presenting original research, contributors provided reflections on the state of their subfields and showed how examples derived from the study of Shiism can complicate and enrich debates in broader fields and disciplines. Matthijs van den Bos provided an overview of the fortunes of the modern (primarily Twelver) Shia in Europe. Edith Szanto gave a rich contextualization of the periodization of ethnographies of Shii women over the last several decades. Edmund Hayes surveyed the state of the field of approaches to the Shii hadith corpora. Gurdofarid Miskinzoda provided a narratological analysis of Shaykh Mufïd's Kitāb al-Irshād as well as a bird's eye view of the field of Shii studies on the basis of her experience at the pivotal Institute for Ismaili Studies in London. Mirjam Künkler offered an overview of a new edited volume on female religious authority, with some particular details on Bint al-Hudā. Tahera Qutbuddin focused on the relationship between piety and virtue as expounded in the Nahjal-balägha and pushed back against the exclusive categorization of such texts as "Shii" when their primary function may be, for example, showcasing rhetorical mastery rather than making sectarian claims. Ab de Jong provided a critique of Western scholars' strategies for "domesticating Shiism" into 
frameworks commensurable with the worldviews of their audience, namely, ethnicity, philosophy, esotericism, and politics. In particular, De Jong took aim at Patricia Crone, who, he argued, ignored several possible understandings of what monotheism could be to rely on one conception alone: the monotheism of a just God, separated from mankind as an impartial arbiter. This privileging of one "proper" understanding of monotheism, he argued, has the effect of positioning of Shii Islam as intrinsically heretical, a move to be avoided by dispassionate scholars. Deborah Tor made the case for the importance of understanding Shii Islam not as marginal but as central to early Islamic history. As Tor argued, Shiism played a key role in the loss of legitimacy of the office of the caliph under the Abbasids, which gave rise to the authority structures of Sunni Islam as we know them. Robert Gleave, in his keynote presentation, discussed the positioning of scholarship on Shiism and warned of the necessity of steering between two potential dangers: the risk that other fields might ignore Shii themes (as often they do), on the one hand, and the converse danger that the growth of Shii studies into a strong independent field might separate it from Islamic studies and Islamic history more broadly and encourage the production of scholarship in a self-contained silo. In addition to the academic papers, the conference participants heard a panel discussion on issues facing Shii Muslims in the Netherlands featuring Magreet van Es from Radboud University Nijmegen, Anne Dijk, director of the Fahm Institute, and her collaborator Arjen Buitelaar, who together coordinate events such as Sunni-Shii iftārs and other activities for "Su-Shi" interfaith dialogue.

The conference was organized by Gabrielle van den Berg, Ahab Bdaiwi, Radhika Gupta, Edmund Hayes, and Rutger Veltman. 